\title{
An in vitro study of potential attachment sites for the reconstruction of the medial collateral ligament of canine stifles
}

\author{
Estudio in vitro sobre potenciales puntos de anclaje para la reconstrucción \\ del ligamento colateral medial en rodillas caninas \\ C Fischer ${ }^{\mathrm{a}}$, JC Alarcón ${ }^{\mathrm{a}}$, IE Troncoso ${ }^{\mathrm{a}}$, MD Cherres ${ }^{\mathrm{b}}$ \\ ${ }^{a}$ Escuela de MedicinaVeterinaria, Universidad Santo Tomás, Concepción, Chile.

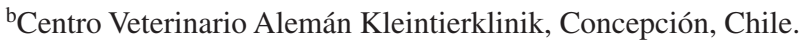

\begin{abstract}
RESUMEN
La ruptura del ligamento colateral medial conlleva a inestabilidad articular de la rodilla en perros y debe ser reparada quirúrgicamente lo antes posible. El posicionamiento del implante en una posición isométrica es necesario para mantener la estabilidad articular evitando tensiones excesivas o aflojamiento del implante durante el movimiento articular. El objetivo del presente estudio fue determinar la isometría potencial de tres combinaciones de anclaje; un anclaje femoral en combinación con tres anclajes en la zona proximal de la tibia en nueve rodillas caninas. Se determinó la distancia entre el marcador femoral y los tres distintos marcadores tibiales en radiografías de cada rodilla en tres distintos ángulos articulares (extensión máxima, $130^{\circ}$ y máxima flexión). Ninguna combinación estudiada resultó isométrica. Todas las combinaciones demostraron un leve aumento de la distancia en extensión del miembro y una reducción marcada de la longitud en máxima flexión articular. El menor cambio total de longitud se encontró en el marcador tibial más distal. El presente estudio demuestra que hay variación de longitud entre distintos puntos posibles de anclaje para la reparación del LCM y puede ser la base para futuras investigaciones relacionadas con dicha lesión.
\end{abstract}

Palabras clave: rodilla canina, ligamento colateral, isometría.

\section{SUMMARY}

Rupture of the medial collateral ligament (MCL) results in joint instability of the stifle in dogs and should be surgically repaired as early as possible. Placement of a prosthetic ligament in the most isometric position is necessary to maintain joint stability avoiding excessive tension or loosening on the implant during joint motion. The objective of the present study was to determine the potential isometry of three anchor paired sites in canine cadaveric stifles. The length from a femoral marker to each of 3 medial tibial markers was determined from radiographs of each limb in different joint angles (maximal extension, $130^{\circ}$ and maximal flexion). None of the anchor combinations were isometric. All combinations had low increase in length on stifle extension and a pronounced decrease on stifle flexion. The least change in length was measured on the more distal tibial anchor marker. The present study demonstrates that some locations for the origin and insertion of a prosthetic MCL are associated with less length change.

Key words: canine stifle, collateral ligament, isometry.

\section{INTRODUCTION}

Medial collateral ligament (MCL) injury due to traumatic incidents or chronic joint infection affecting ligament structures cause joint instability (Aron 1988, Brinker et al 2006, Bruce 1998). These injuries are either treated with primary reconstruction of the ligament, with a prosthetic ligament (Piermattei and Johnson 2004, Hulse and Shires 1986), transarticular external fixators or splint stabilization of the joint until adequate periarticular fibrosis is achieved (Laing 1993). Meniscal and cruciate damage should always be suspected with any collateral ligament injury severe enough to produce instability of the joint (Piermattei and Johnson 2004).The placement of the prosthetic ligament in

Accepted: 16.10.2014.

* Avda. Prat 897, Concepción, Chile; cfischer@ santotomas.cl the most isometric position is necessary to maintain joint stability, avoiding excessive tension or loosening on the implant during joint motion. Both collateral ligaments are taut in extension and prevent internal tibial rotation with the cruciate ligaments. In extension, collateral ligaments are the primary stabilizers of lateral (valgus) and medial (varus) angulations of the tibia. When the stifle joint flexes, the lateral collateral ligament (LCL) becomes les taut and allows internal tibial rotation which is limited only by the cruciate ligaments, while the MCL remains taut and is the primary stabilizer of external tibial rotation. When the MCL is completely ruptured, there is an increase in valgus motion and increased tibial rotation in flexion (Vasseur et al 1981). When primary repair of the medial collateral ligament cannot be achieved, and when that repair is considered so weak that it is likely to fail with normal physiological load, the placement of a prosthetic ligament should be anatomically positioned to maintain 
equal length and tension throughout the range of motion of the joint (isometric placement). Investigations associated with isometric patterns for ligaments repair in the canine stifle and in the human knee can be found in the literature (Roe et al 2008, Fischer et al 2010, Hulse et al 2010, Lee et al 2012, Jung et al 2013), but to our knowledge there are no data published to date regarding the isometry of the MCL in dogs. The goal of the present study was to determine the effect of three tibial anchor points on the change in length in three different joint angles in canine stifles.

\section{MATERIAL AND METHODS}

Nine pelvic limbs were obtained by coxofemoral disarticulation from 5 adult orthopedically sound dogs euthanatized for reasons unrelated to this study. For inclusion, stifles had to be free of any gross morphologic abnormality on mediolateral radiographs. Limbs were double sealed in plastic bags and immediately frozen at $-18^{\circ} \mathrm{C}$ and thawed at room temperature for 24 hours before testing.

Limbs were prepared for testing by complete skin removal. The periarticular tissues of the stifle and the muscles surrounding the tibia were preserved. The femur was fixed in a vertical position with a custom made holder, allowing for unconstrained manipulation of the stifle, tibia, and tarsus. A plastic goniometer was placed lateral to the stifle for measurement of joint angle. The arms of the goniometer were aligned at the greater trochanter, the lateral epicondyle, and the longitudinal axis of the tibia (Jaegger et al 2002).

Four Kirshner wires, 1,5 mm diameter, were drilled in each limb and used as markers. One marker in the origin of the MCL and three markers in the insertion of the MCL. The landmarks for placing the insertions markers were the most distal part of the insertion of the MCL, the most proximal part of the insertion of the MCL and the length between these two points was divided into two equally spaces. Mediolateral radiographs were taken of each stifle in 3 different joint angles (maximal extension, $130^{\circ}$ and maximal flexion) (figure 1 ). No attempt was made to control tibial rotation.

The length from the center of the femoral marker (origin of the MCL) to the centre of each tibial marker at each joint angle for each stifle was measured using an electronic micrometer $( \pm 0.01 \mathrm{~mm})$ (Mitutoyo Model \# 505-633-50 America Corporation, Aurora, IL, USA) and recorded in a spreadsheet program (Microsoft Excel 2007, Microsoft Corporation, Redman, WA, USA). The change in length, expressed as a percent of the length measured at $130^{\circ}$, was calculated for each marker at each position of the stifle joint. The mean $( \pm \mathrm{SD})$ was calculated for the nine joints for each distance at each joint angle.

\section{DATA ANALYSIS}

Descriptive statistics were performed with statistical software (SPPS 13.0 for Windows, SPSS Inc., Chicago, IL and confidence interval analysis [CIA], v.2.1.2, University of Southampton, Southampton, UK). All data were tested for normal distribution using the Kolmogorov-Smirnov Test. As the assumption of normality was rejected, median and associated interquartile range (IQR) were calculated for each of the 3 joint angles for the 3 anchor combinations. Differences between the anchors were determined using

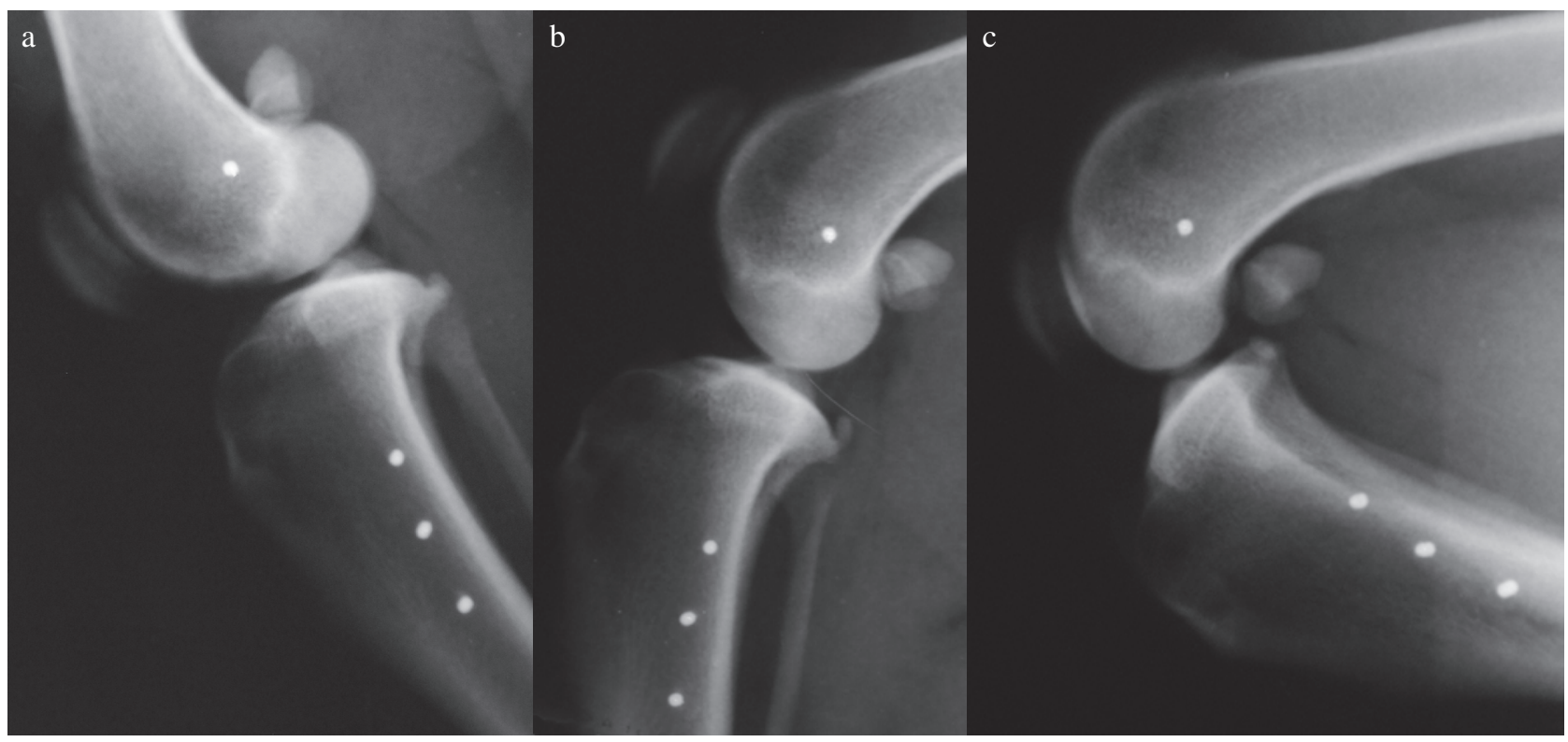

Figure 1. Medial-lateral radiographs of a canine stifle in three different joint angles (figure 1a: extension, figure $1 \mathrm{~b}: 130^{\circ}$ and figure 1c: flexion) demonstrating the placement of a marker in the medial aspect of the condyle and three markers in the tibia.

Radiografías medio-laterales de una rodilla canina en tres ángulos articulares (Figura 1a: extensión, figura 1b: $130^{\circ}$ y figura 1c: flexión) demostrando la posición de un marcador en la zona medial del fémur y tres marcadores en la tibia para la obtención de las mediciones. 
the $95 \% \mathrm{CI}$ of the median difference (CI Diff), being considered significantly different if the CI Diff did not include 0 (Garner and Altman 2005).

\section{RESULTS AND DISCUSSION}

A graphical representation of the mean change of length of the distance between the origin and insertion of the medial collateral ligament is presented in figure 2 . Overall, the 3 anchor combinations resulted in a uniform length pattern along a full ROM of the stifle, with an increase in length at full extension of the stifle and a decrease in length at maximal flexion. The length between the FM and the proximal insertion marker (PIM) had an overall variation (change of total length from flexion to extension) of $5.95 \%$, increased $1.26 \%$ in full extension and decreased to $4.69 \%$ in flexion. The length between the FM and the midpoint insertion marker (MIM) had an overall variation of $6 \%$, increased $0.007 \%$ in full extension and decreased to $5.996 \%$ in flexion. The length between the FM and the distal insertion marker (DIM) had an overall variation of $4.52 \%$ increased $0.26 \%$ in full extension and decreased to $4.26 \%$ in flexion. The combination between the FM and the DIM result in the least change in length among the 3 combinations. Analysis of CI Diff among the 3 anchor combinations are presented in table 1. MIM was significantly different compared with the DIM (95\% CI Diff $=-8.59 \mathrm{~mm}$ to $-7.25 \mathrm{~mm}$ ), whereas the PIM was

Table 1. Median and associated Interquartile Range (IQR) of the change in length for the 3 anchor combinations (proximal, midpoint and distal), as well as the comparison of the 3 markers to each other using 95\% Confidence Interval Analysis of the median difference (95\% CI Diff).

Mediana y el rango intercuartil (IQR) de la longitud en relación con las tres combinaciones de anclaje (Proximal, midpoint y distal), como la comparación entre los tres marcadores utilizando el análisis de la diferencia de la mediana (95\% CI Diff) con un intervalo de confianza $95 \%$.

\begin{tabular}{|c|c|c|c|c|}
\hline \multirow{2}{*}{\multicolumn{2}{|c|}{ Median of the total length (IQR) (mm) }} & \multicolumn{3}{|c|}{$\begin{array}{l}\text { Median difference in change in length } \\
(\mathrm{mm} ; 95 \% \text { CI Diff })^{*}\end{array}$} \\
\hline & & \multirow{2}{*}{$\begin{array}{c}\text { Proximal } \\
0\end{array}$} & \multirow{2}{*}{$\begin{array}{c}\text { Midpoint } \\
1.08 \\
(-5.48 \text { to } 7.66)\end{array}$} & \multirow{2}{*}{$\begin{array}{c}\text { Distal } \\
-6.83 \\
(-13.69 \text { to } 0.02)\end{array}$} \\
\hline Proximal & $\begin{array}{c}36.29 \\
(26.44 \text { to } 47.11)\end{array}$ & & & \\
\hline Midpoint & $\begin{array}{c}34.84 \\
(26.51 \text { to } 46.43)\end{array}$ & 1.08 & 0 & $\begin{array}{c}-7.92^{\mathrm{a}} \\
(-8.59 \text { to }-7.25)\end{array}$ \\
\hline Distal & $\begin{array}{c}44.17 \\
(33.27 \text { to } 54.53)\end{array}$ & -6.83 & $-7.92^{\mathrm{a}}$ & 0 \\
\hline
\end{tabular}

Data expressed in millimeters $(\mathrm{mm})$.

*Any CI Diff excluding 0 indicates a significant difference between the 2 groups evaluated.

${ }^{a}$ Significant difference based on the calculation of CI Diff. 95\% CI Diff, 95\% confidence interval of the median difference.

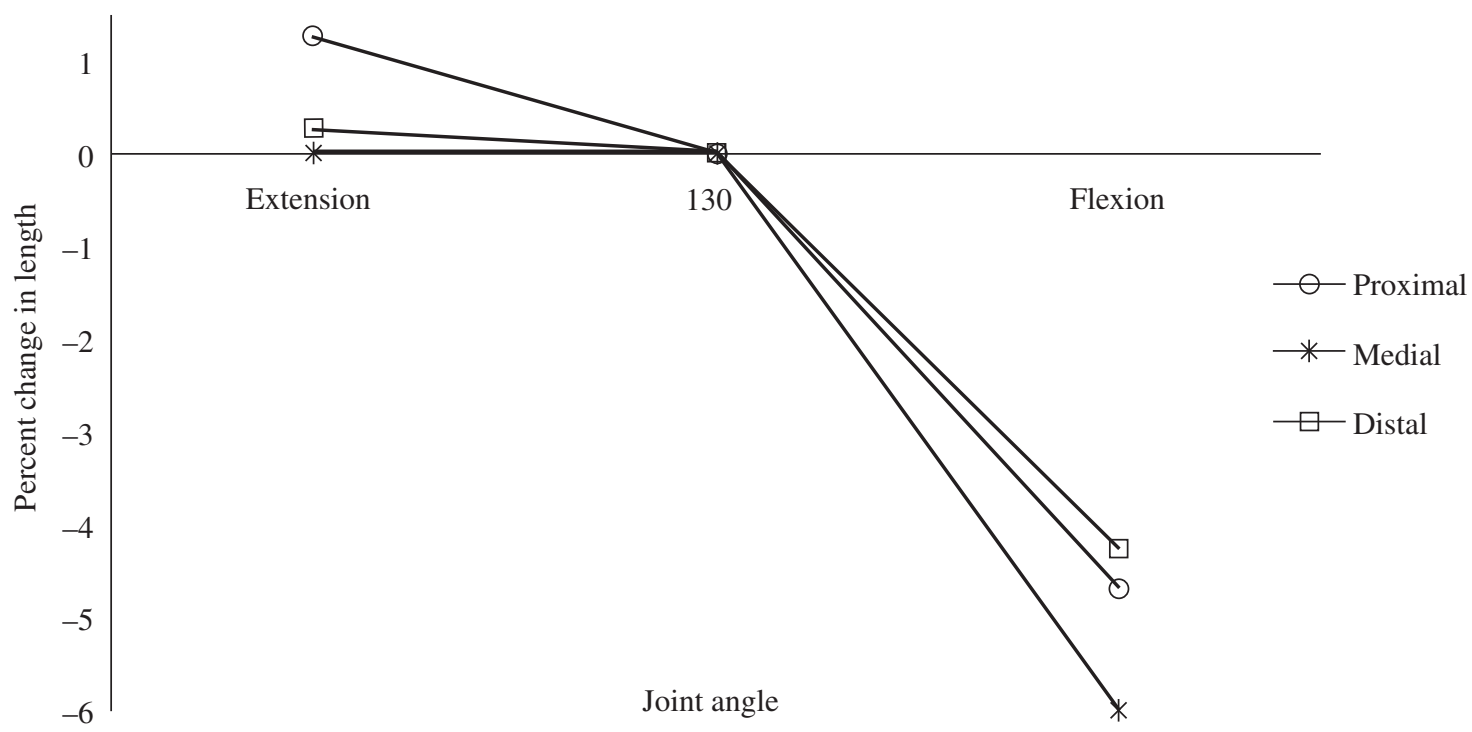

Figure 2. Percent change in length of the length from the femoral marker to the three tibial markers. The stance joint position $\left(130^{\circ}\right)$ was chosen as the 'zero' point.

Cambios de longitud en porcentajes de la distancia entre el marcador femoral y los tres marcadores tibiales. La posición articular de estancia $\left(130^{\circ}\right)$ fue elegida como el punto "cero". 
not different among the other 2 combinations (95\% CI Diff $=-5.48 \mathrm{~mm}$ to $7.66 \mathrm{~mm})(95 \%$ CI Diff $=-13.69 \mathrm{~mm}$ to $0.02 \mathrm{~mm}$ ). Our results show that the 3 combinations studied had substantial changes in length during a full range of stifle motion. There is a tendency for the three combinations studied to shorten throughout flexion and to enlarge throughout extension of the stifle joint. This results correlate to the reported function of the MCL (Vasseur et al 1981).

The MCL is a complex structure and the collagen fibers are taut or lax at different joint angles. As such, there is no true isometric point, particularly for suture stabilization of the joint. Nevertheless, suture tension can be maintained near constant if the femoral and tibial paired sites are near isometric. The isometric paired site was the combination between the femoral with distal anchor. Factors such as weight bearing loads and material properties of the suture (stress and relaxation) affect breakage and elongation, isometric sites may help reduce suture tension and premature suture failure (Hulse et al 2010). The forces imposed on a suture used for stabilization are unknown. As such, the necessary structural strength and stiffness of the suture and the material property of the suture (creep, stress and relaxation) are also not known. Uncontrolled activity postoperatively may cause excessive tension in the suture used for stabilization causing breakage or elongation. If this occurs prior to strengthening of secondary restraints (periarticular fibrosis), failure and instability are likely to result. Further clinical studies are necessary to determine if the isometric suture attachment sites noted in this study is more clinically effective than other sites for suture attachment.

Several technical factors may contribute to the differences in length of the studied anchor points including variability of marker placement and variability of origin and insertion sites. Small rotations of the bones, principally internal or external rotation of the tibia could produce errors in measurements, changing the relative position of the markers to radiographs.

The optimal anchor sites for the replacement of the MCL have not been determined. The present literature (Paatsama 1952, Farrow 1978, Parker y Schubert 1981, Vasseur et al 1981, Smith 1985, Vasseur 2003, Brinker et al 2006, Schulz 2007), do not describe where the anchor should be located in order to ensure that the suture will function optimally.

We concluded that altering the attachment points when performing the reconstruction of the MCL can change the distance within the suture throughout extension and flexion of the stifle. Regardless of the anchor combination, an increase in distance between two anchor sites can lead to suture breakage and irreversible stretch, and a decrease in distance between two anchor sites in flexion will lead to insufficient stabilisation of the stifle.

\section{REFERENCES}

Aron D. 1988.Traumatic dislocation of the stifle joint: treatment of 12 dogs and one cat. J Am Anim Hosp Assoc 24, 333.

Brinker WO, DL Piermattei, GL Flo. 2006. Collateral ligament injuries. In: Handbook of Small Animal Orthopedics and Fracture Repair. $4^{\text {th }}$ ed. Saunders, Philadelphia, USA, Pp 617-619.

Bruce WJ. 1998. Multiple ligamentous injuries of the canine stifle joint: a study of 12 cases. J Small Anim Pract 39, 333-340.

Fischer C, M Cherres, V Grevel, G Oechtering, P Böttcher. 2010. Effects of attachment sites and joint angle at the time of lateral suture fixation on tension in the suture for stabilization of the cranial cruciate ligament deficient stifle in dogs. Vet Surg 39, 334-342.

Farrow CS. 1978. Sprain, strain, and contusion. Vet Clin North Am 8, 169.

Garner M, D Altman. 2005. Confidence intervals rather than P values. In: Altman D, Machin D, Bryant T, Garner M (eds). Statistics with Confidence. $2^{\text {nd }}$ ed. BMJ Books, London, UK, Pp 15-27.

Hulse DA, P Shires. 1986. Multiple ligament injury of the stifle joint in the dog. J Am Anim Hosp Assoc 22, 105.

Hulse D, W Hyman, B Beale, B Saunders, L Peycke, G Hosgood. 2010. Determination of isometric points for placement of a lateral suture in treatment of the cranial cruciate ligament deficient stifle. Vet Comp Orthop Traumatol 23, 163-167.

Jaegger G, DJ Marcellin-Little, D Levine. 2002. Reliability of goniometry in Labrador Retrievers. Am J Vet Res 63, 979-986.

Jung HJ, JH Kim, HJ Lee, S Koo, SH Chang, YB Jung, SH Lee. 2013. The isometry of two different paths for remnant-preserving posterior cruciate ligament reconstruction. Knee Surg Sports Traumatol Arthrosc 21, 1029-1035.

Laing EJ. 1993. Collateral ligament injury and stifle luxation. Vet Clin North Am 23, 845-853.

Lee JS, TH Kim, SY Kang, SH Lee, YB Jung, S Koo, SH Chang, WB Lee, HJ Jung. 2012. How isometric are the anatomic femoral tunnel and the anterior tibial tunnel for anterior cruciate ligament reconstruction? Arthroscopy 28, 1504-1512.

Paatsama S. 1952. Ligament injuries in the canine stifle joint. A clinical and experimental study. Doctoral thesis. Helsinki University, Helsinky, Finland.

Parker RB, TA Schubert. 1981. Repair of ligamentousjoint injuries in three dogs using spiked washers. J Am Anim Hosp Assoc 17, 45-50.

Roe SC, J Kue, J Gemma. 2008. Isometry of potential suture attachment sites for the cranial cruciate ligament deficient canine stifle. Vet Comp Orthop Traumatol 21, 215-220.

Schulz K. 2007. Disease of the joints: stifle. In: Fossum TW, Hedlund CS, Johnson AL, Schulz K, Seim HB, Bahr A, Carroll GL (eds). Small Animal Surgery. $3^{\text {rd }}$ ed. Mosby, St. Louis, USA, Pp 1254-1276.

Smith GK. 1995. The principles for repair of multiple ligamentous injuries of the stifle. $22^{\text {nd }}$ Annual Conference of Veterinary Orthopaedic Society, Whistler, B.C., Canada.

Vasseur PB, P Steven, S Arnoczky. 1981. Collateral ligaments of the canine stifle joint: anatomic and functional analysis. Am J Vet Res 42, 1133-1137.

Vasseur PB. 2003. Stifle Joint. In: Slatter D (ed). Textbook of Small Animal Surgery. $3^{\text {rd }}$ ed. Elsevier Science, Philadelphia, USA, Pp 2090-2133. 